\title{
Response of benthic microbial communities to chitin enrichment: an in situ study in the deep Arctic Ocean
}

\author{
Corinna Kanzog • Alban Ramette • Nadia V. Quéric • \\ Michael Klages
}

Received: 27 January 2008 / Revised: 18 August 2008 / Accepted: 19 August 2008 / Published online: 3 September 2008

(C) The Author(s) 2008. This article is published with open access at Springerlink.com

\begin{abstract}
In situ enrichment experiments were carried out in the Arctic deep sea (Fram Strait region) to observe the response of benthic microbial communities to chitin supply. Chambers of a benthic lander were filled in July 2004 with deep-sea sediments enriched with $1.3-7.0 \mathrm{~g} \mathrm{~m}^{-2}$ of chitin and the effects of chitin enrichment were assessed on the microbial hydrolytic activity potential, cell number and community structure after periods of 1 week and 1 year of in situ deployment. The input of chitin had no effect on microbial abundance and chitobiase activity after 7 days of incubation, whereas community structure in enriched sediments, determined by terminal restriction fragment length polymorphism analysis of 16S rRNA genes, was different from the controls. After 1 year, microbial numbers and activity significantly increased in sediments enriched with high chitin concentrations and bacterial community structure was different from that of the other treatments. The present study suggests that microbial community structure in Arctic deep-sea sediments can react quickly to sudden large chitin inputs into the sediments and that this appears to precondition subsequent enhanced growth and enzymatic activity changes.
\end{abstract}

Electronic supplementary material The online version of this article (doi:10.1007/s00300-008-0510-4) contains supplementary material, which is available to authorized users.

C. Kanzog $(\varangle) \cdot$ N. V. Quéric · M. Klages

Alfred Wegener Institute for Polar and Marine Research, Am Handelshafen 12, 27570 Bremerhaven, Germany

e-mail: Corinna.Kanzog@awi.de

A. Ramette

Microbial Habitat Group, Max Planck Institute for Marine Microbiology, Celsiusstr. 1, 28359 Bremen, Germany
Keywords Chitin · Deep-sea sediments . Microbial communities

\section{Introduction}

Sinking particulate organic matter (POM) that reaches the deep seafloor mainly consists of less degradable material including cellulose, chitin and various proteinaceous structural compounds (Wakeham and Lee 1993). As a major component of cuticles and exoskeletons of worms, molluscs and arthropods, chitin is probably the most important biopolymer in marine environments (Gooday 1990). Although other organisms may be able to decompose chitin, the breakdown of such degradation-resistant organic matter deposited in deep-sea sediment surfaces is mainly accomplished by bacteria which are able to extracellularly cleave structural polymeric compounds (Deming and Baross 1993).

A variety of time course experiments have been performed to test the functional responses of benthic deep-sea bacteria to chitin input [e.g. North Atlantic (Deming 1985); Arctic continental slope (Boetius and Lochte 1996); Arabian Sea (Christiansen and Boetius 2000)]. These studies indicated that chitin supplies induced the synthesis of specific enzymes and that indigenous deep-sea bacteria were able to decompose even high amounts. Previous experiments were conducted under laboratory conditions and did not provide detailed information on the variation in microbial community over periods longer than weeks. In situ experiments focussing on microbial response to organic enrichments in the deep-sea are scarce (e.g. Moodley et al. 2002; Bühring et al. 2006), especially in Polar regions.

Studies have reported mass sedimentation events of crustaceans in different ocean regions (Sokolova 1994; 
Christiansen and Boetius 2000), which represent a high input of chitinous material. The fact that high concentrations of the Arctic copepod Calanus hyperboreus were repeatedly observed over the ocean floor of the Greenland Sea (Hirche et al. 2006) suggests that high amounts of chitinous material would be naturally available when this large aggregation of organisms dies or moults. In addition, shifts in the distribution and abundance of key copepod species from the Arctic Ocean, possible caused by environmental changes associated with climate changes (Węsławski and Legeżyńska 1998; Hirche and Kosobokova 2007), may also contribute to enhanced chitin input to the deep seafloor. Investigations are necessary to better understand the effects of chitin supply on deep-sea microbial assemblages as main agents in the mineralisation of chitinous material. Here, for the first time, short-term (7 days) and long-term (1 year) incubation experiments were carried out in situ to assess the effects of varying concentrations of chitin on microbial communities in Arctic deep-sea sediments. We tested the hypothesis that a higher amount of chitin introduced into the sediments leads to increased microbial growth, activity and possibly to significant changes in bacterial community structure.

\section{Materials and methods}

\section{Experimental design}

A free-falling benthic lander, containing deep-sea sediments enriched with different chitin concentrations, was deployed for 7 days and 1 year at 2,500 $\mathrm{m}$ water depth in the long-term observatory HAUSGARTEN $\left(79^{\circ} 5^{\prime} \mathrm{N} /\right.$ $4^{\circ} 2^{\prime} \mathrm{E}$ ), in the eastern Fram Strait, west off Svalbard (Soltwedel et al. 2005). The lander was designed by the Institut Français de Recherche pour l'Exploitation de la Mer (IFREMER) and consisted of four identical trays, each of which was equipped with four separate chambers $\left(0.02 \mathrm{~m}^{2}\right)$. Only one tray was used for our enrichment experiments.

Natural deep-sea sediments from the central HAUSGARTEN station were collected with a multiple corer (MUC; Barnett et al. 1984) at 2,505 m water depth on 9 July 2004 during the cruise ARK XX/1 with RV 'Polarstern'. Sediments were composed of a mixture of $37 \%$ sand (particle size $63-2,000 \mu \mathrm{m}), 43 \%$ silt $(4-63 \mu \mathrm{m})$ and $20 \%$ clay $(<4 \mu \mathrm{m})$. Surface sediments $(0-3 \mathrm{~cm})$ of several sediment cores were pooled and transferred into lander chambers. Following sediment freezing at $-30^{\circ} \mathrm{C}$ for $48 \mathrm{~h}$ and subsequent thawing, a 'low', 'medium' and 'high' chitin concentration corresponding to $1.3,3.0$ and $7.0 \mathrm{gm}^{-2}$ chitin (purified chitin flakes from crab shells, Sigma-Aldrich, Germany), respectively, were mixed with the upper layers of the sediments placed in the chambers. The additions were equivalent to a substrate input of $0.5-3.0 \mathrm{~g} \mathrm{C} \mathrm{m}^{-2}$, which are well above the background value of chitin in deep-sea sediments of $0.1 \mathrm{mg} \mathrm{m}^{-2}$ (Poulicek and Jeuniaux 1989). A control treatment consisted of one chamber filled with deep-sea sediments without any addition of organic substrate. Before deployment, sediment samples were taken for initial analysis of microbial parameters (0 day).

Sub-sampling and sample processing

During RV 'Polarstern' cruise ARK XX/1 in July 2004, the benthic lander was deployed for 7 days. In order to prevent disturbance of the sediments inside the chambers, the trays were closed during transport in the water column and opened again after landing at the seafloor by means of a remotely controlled mechanism. After recovery and subsequently sampling, trays were equipped with new chambers. These chambers were filled with sediments obtained from MUC sampling for the short-term experiment which were stored frozen until the deployment. Amendment of sediments with chitin was carried out in the same way as described above. Trays for the long-term experiment were deployed at the same station for 1 year. Sampling of the 1year experiment took place during RV 'Polarstern' expedition ARK XXI/1b in July 2005.

After each recovery of the trays, eight samples from the first centimetre of sediments in each chamber were taken using plastic syringes with cut-off ends $(2.5 \mathrm{~cm}$ in diameter). Sub-sampling was carried out in a room at $4^{\circ} \mathrm{C}$. Sediments from each chamber were pooled and homogenised before determining the abundance, enzymatic activity and changes in bacterial community structure.

\section{Microbial biomass}

For total microbial cell numbers and biomass determination, $2 \mathrm{ml}$ of the sediment sub-sample $\left(2.3 \mathrm{~cm}^{3}\right)$ were taken by means of plastic syringes with cut-off ends $(1.2 \mathrm{~cm}$ in diameter) and stored at $4{ }^{\circ} \mathrm{C}$ in $9 \mathrm{ml} 2 \%$ formaldehyde solution. After staining with acridine orange, total cell counts were determined by epifluorescence microscopy according to Meyer-Reil (1983). Volumetric measurements of the microbial cells were conducted with the New Porton grid, measuring randomly 50 cells per filter (Grossmann and Reichardt 1991). Microbial biomass was estimated using a

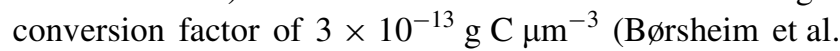
1990). For each sample 40 counted grids from 2 replicate filters were analysed.

\section{Enzyme activity}

To assess the chitinolytic activity of microbial organisms, we used the assay for chitobiase activity, providing a 
simple and sensitive determination of extracellular enzymatic hydrolysis rates after relatively short incubation time and adaptable at low temperature (Hoppe 1983; Poremba 1995). The extracellular enzymatic activity of chitobiase was measured fluorometrically using the methylumbelliferone (MUF) labelled substrate $N$-acetyl- $\beta$-glucosaminide (Sigma-Aldrich; Boetius and Lochte 1994). Previous trials to determine the substrate saturation level gave a final concentration of $100 \mu \mathrm{mol} \mathrm{MUF-substrate.} \mathrm{Relative} \mathrm{units}$ of fluorescence were calibrated with seven MUF standard concentrations between 10 and $300 \mathrm{nmol}$. The enzyme activity was calculated per volume of sediment and time $\left(\mu \mathrm{mol} \mathrm{cm} \mathrm{c}^{-3} \mathrm{~h}^{-1}\right)$ by linear regression. The regression coefficient was always better than 0.95 . For each sample three measurements per incubation were performed.

Terminal-restriction fragment length polymorphism (T-RFLP) analysis

Sediment samples for microbial community analysis were stored at $-30^{\circ} \mathrm{C}$ until analysis. Total DNA was extracted and purified using a FastDNA ${ }^{\circledR}$ SPIN Kit for soil (Qbiogene, Heidelberg, Germany) following manufacturer's instructions. DNA concentrations ranged from 50 to $80 \mathrm{ng} \mu \mathrm{l}^{-1}$.

Analysis of community structure focussed exclusively on bacterial groups since they are one of the most important agents in the mineralisation of chitin (Cottrell and Kirchman 2000). The primers used for amplification of eubacterial $16 \mathrm{~S}$ rDNA were $27 \mathrm{~F}$ and 1492R (both synthesised by Interactiva; Ulm, Germany) (Rappé and Giovannoni 2003). The bacterial specific forward primer $27 \mathrm{~F}$ was end-labelled with phosphoramidite fluorochrome 5-carboxyfluorescein (5'6-FAM). The PCR mixture contained $2 \mu$ l of template DNA, $0.25 \mu \mathrm{mol}$ (each) primer, $1.5 \mathrm{mmol} \mathrm{KCl}, 10 \mathrm{mmol}$ Tris- $\mathrm{HCl} \mathrm{pH} 9,1.5 \mathrm{mmol} \mathrm{MgCl}_{2}, 250 \mu \mathrm{mol} \mathrm{dNTP}$, and 1.25 U Taq-Polymerase (Amersham Pharmacia Biotech, Freiburg, Germany) in a final volume of $50 \mu \mathrm{l}$. DNA amplification was performed by using the following cycling conditions: a 3-min hot start at $95^{\circ} \mathrm{C}$, followed by 29 cycles consisting of denaturation $\left(1 \mathrm{~min}\right.$ at $\left.95^{\circ} \mathrm{C}\right)$, annealing $\left(1 \mathrm{~min}\right.$ at $\left.55^{\circ} \mathrm{C}\right)$, and extension $\left(1 \mathrm{~min}\right.$ at $\left.72^{\circ} \mathrm{C}\right)$. A final extension at $72^{\circ} \mathrm{C}$ was then done for $7 \mathrm{~min}$. Fluorescently labelled PCR products were run onto $1 \%$ agarose gel and purified using QIAquick Gel Extraction kit (Qiagen, Hilden, Germany) following the manufacturer's instructions. Approximately $300 \mathrm{ng}$ of the PCR product was digested with $10 \mathrm{U}$ of endonucleases HhaI and MspI (Amersham Pharmacia Biotech). The digestions were performed separately in a total volume of $50 \mu \mathrm{l}$ at $37^{\circ} \mathrm{C}$ for $5 \mathrm{~h}$. Restriction digestions were desalted (isopropanol 100\%) and dried prior to storage at $-20^{\circ} \mathrm{C}$. Fragment separation was performed by Gene Analysis Service GmbH (Berlin, Germany) using an ABI Prism 310 capillary analyser (PE
Applied Biosystems, CA, USA). Peak size determination of end-labelled fragments, considered here as different Operational Taxonomic Units (OTUs), was done by comparison with an internal size standard (GS2500 TAMRA, PE Applied Biosystems). Peaks between 50 and 1,000 base pairs long were analysed using Genescan analytic software 2.02 (ABI). An additional check for artefacts was manually performed and peaks whose areas were smaller than $1 \%$ of the total peak area were excluded from data analysis. Due to the limited amount of available sediment samples, T-RFLP analyses were done once for each treatment.

Data analysis

Microbial cell number and chitobiase activity were $\log _{10^{-}}$ transformed prior to performing statistical analyses in order to normalise their distribution and homogenise treatments variances (Crochan test of homogeneity, Sokal and Rohlf 1995). Analysis of variance (ANOVA) was applied to each data set to test the effects of chitin input and incubation time, and of their interactions. Post-hoc comparisons between treatment means were done using Tukey's honestly significant difference (HSD) test at $P<0.05$.

T-RFLP fingerprints obtained from the two different restriction digests were combined to generate a binary matrix according to the presence or absence of bacterial OTUs. The unweighted pair group with arithmetic mean (UPGMA) method was applied with the Dice similarity index (Dice 1945). Nodal support in the resulting dendrogram was determined by performing 100 bootstrap replicates (Hammer et al. 2001). In addition, non-metric multidimensional scaling was used to obtain an ordination of the samples based on a matrix of Dice dissimilarities of T-RFLP profiles (Ramette 2007). A canonical redundancy analysis (RDA) was used to determine how well different factors could explain the variation in community structure, and in order to assess the respective importance of the different factors and of their covariation on shaping community structure, a variation partitioning procedure (Ramette and Tiedje 2007) was subsequently applied to the community data. Statistical analyses were performed with the statistical software JMP IN version 5.1 (SAS Institute, Cary, NC, USA) and with the R package ( $\mathrm{R}$ version 2.4.0; The $\mathrm{R}$ foundation for Statistical Computing).

\section{Results and discussion}

Effects of chitin addition on microbial abundance and activity

Changes in microbial biomass were mainly explained by variation in microbial cell numbers and less by changes in 
Table 1 Analysis of variance of microbial abundance and activity as a function of chitin input and incubation time

\begin{tabular}{|c|c|c|c|c|}
\hline Source & Sum of squares & $d f^{\mathrm{b}}$ & Mean square & $F$ ratio $^{c}$ \\
\hline \multicolumn{5}{|l|}{ Microbial cell number ${ }^{\mathrm{a}}$} \\
\hline Chitin input & 0.51 & 3 & 0.17 & $153.404 * * *$ \\
\hline Incubation time & 1.313 & 2 & 0.656 & $592.487 * * *$ \\
\hline Chitin input $\times$ Incubation time & 0.409 & 6 & 0.068 & $61.537 * * *$ \\
\hline \multicolumn{5}{|l|}{ Chitobiase activity } \\
\hline Chitin input & 21.252 & 3 & 7.084 & $201.375^{* * *}$ \\
\hline Incubation time & 21.617 & 2 & 10.808 & $307.248 * * *$ \\
\hline Chitin input $\times$ Incubation time & 42.598 & 6 & 7.1 & $201.822 * * *$ \\
\hline
\end{tabular}

${ }^{a}$ The total cell number was $\log _{10}$ transformed prior to performing statistical analyses to normalise its distribution

b Degrees of freedom

c The $F$ ratios were all highly significant with $P<0.001(* * *)$

Fig. 1 Microbial cell number (a) and chitobiase activity (b) in control and chitin enriched sediments after 7-day and 1-year incubations. Bars represent mean values \pm SD calculated from replicate samples. Different letters $(A, B, C)$ above the bars indicate significant differences between mean treatments as determined by post hoc Tukey's HSD tests at $P<0.05$

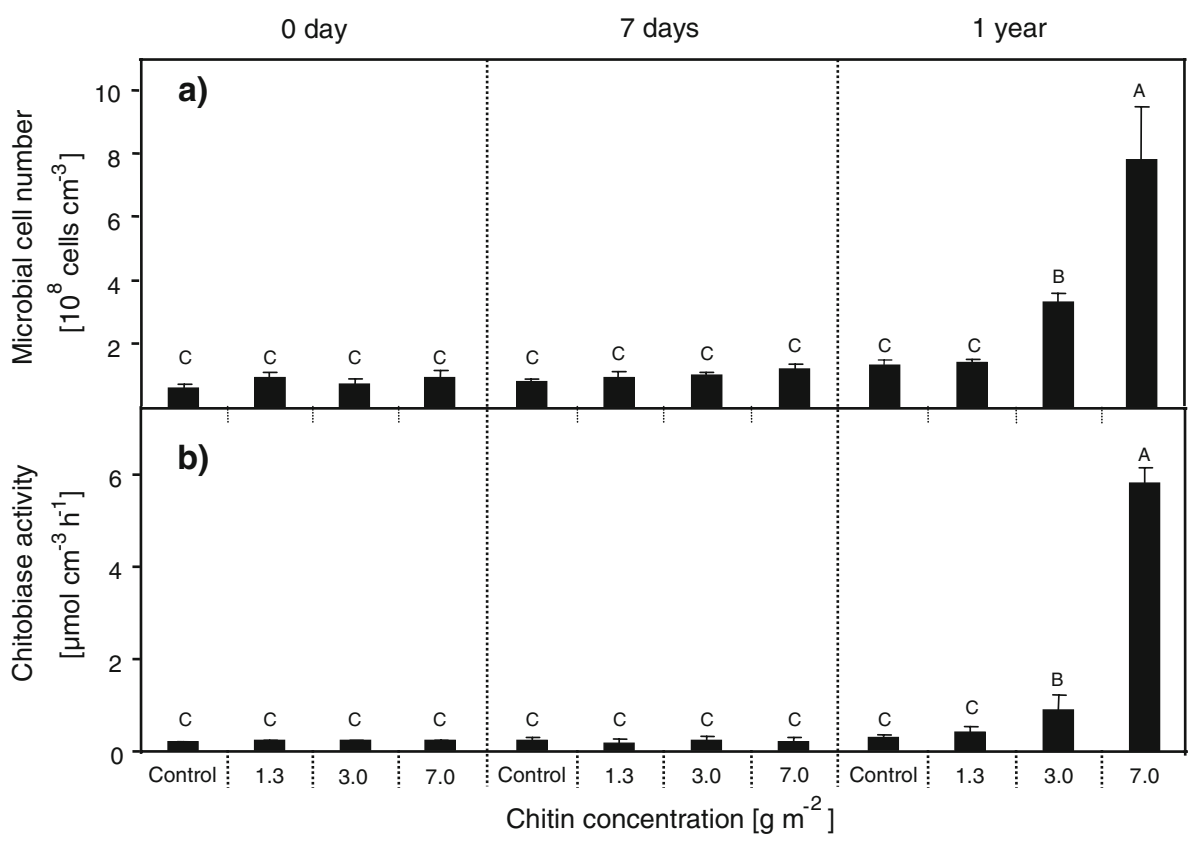

cell volume (data not shown), thus we mainly focussed our analysis on variations in microbial cell numbers. Each factor taken alone (chitin input and incubation time) as well as the interaction between factors had highly significant effects on microbial abundance and chitobiase activity (Table 1). In sediments incubated for 1 week, regardless of the chitin amounts added, no significant changes in microbial abundance were observed and initial chitobiase activity also remained constantly low in all treatments (Fig. 1a, b). These results indicate that within 1 week, a pulse input of chitin to the seafloor has no effect on microbial cell numbers and chitobiase activity. These observations are corroborated by other enrichment studies with deep-sea sediments which have shown time lags for the microbial response to nutrient pulses of up to 2 weeks (e.g. Witte et al. 2003). More specifically, Boetius and Lochte (1996) detected an increase in chitobiase activity 10 days after chitin addition. Investigations of Deming (1985) with deep-sea sediments amended with chitin showed that bacterial doubling time were in the order of weeks or months. Thus, bacterial growth is sufficiently slow to preclude detection of significant increases in cell number after 7 days of incubation.

After 1-year incubation substantial increases of microbial cell number associated with increasing chitin concentrations were observed (Fig. 1a). Total cell counts in the highest $\left(7.0 \mathrm{~g} \mathrm{~m}^{-2}\right)$ and medium $\left(3.0 \mathrm{~g} \mathrm{~m}^{-2}\right)$ chitin amendments were, respectively, about nine and five times higher than prior to incubation, whereas in low chitin amendment $\left(1.3 \mathrm{~g} \mathrm{~m}^{-2}\right)$ only a marginal increase was found. Similar trends were recorded for microbial chitobiase activity (Fig. 1b). The activity levels in control samples and sediments enriched with low chitin amounts were not 
significantly different from the short-term incubation, whereas fourfold and 30-fold activity increases were found in medium and high treatments, respectively (Fig. 1b).

To estimate changes in activity potential that were not related to variation in microbial biomass, chitobiase activity was normalised by the total cell number. The highest chitobiase activity per cell was measured in sediments with highest chitin input after 1 year $\left(7.5 \times 10^{-18} \mathrm{~mol}\right.$ cell $^{-1} \mathrm{~h}^{-1}$ ), which was approximately three times higher than in the other incubations at the same time. Previous investigations on microbial activity in continental slope sediments have shown positive correlations between chitobiase and organic matter supply to the benthos (Vetter and Deming 1994; Boetius and Lochte 1996). Our results showed that chitin amendment of $7.0 \mathrm{~g} \mathrm{~m}^{-2}$ can induce increasing specific chitobiase activity similar to in situ measurements weeks after sedimentation of a large numbers of crab carcasses by Christiansen and Boetius (2000). In general, values for chitin production in oceanic ecosystems are almost inexistent (Cauchie 2002), particularly for Polar regions. According to estimates by Cauchie (2002), total chitin production by crustaceans in marine environments would amount to about $10^{9} \mathrm{t}_{\text {chitin year }}{ }^{-1}$. In particular, the author used a mean value of $40 \mathrm{mg}$ chitin $\mathrm{m}^{-2}$ year $^{-1}$ as an estimation of the combined chitin production by benthic deep-sea macrofauna such as copepods, decapods and isopod. Therefore, a chitin amendment of $7.0 \mathrm{gm}^{-2}$ is larger than the chitin input that may result from the sedimentation of one crab to a square metre of sediment (about $1.0 \mathrm{~g}$; Christiansen and Boetius 2000), and much more than the background chitin value in deep-sea sediments of $0.1 \mathrm{mgm}^{-2}$ (Poulicek and Jeuniaux 1989). Hence, we suggest that, if a large amount of chitinous material naturally becomes available in deep-sea areas, benthic microbial communities may react by a significant increase in their cell numbers and chitinolytic enzyme production. Such a high chitin input would be produced by mass sedimentation of Arctic copepods for example (Hirche et al. 2006), which have a mean chitin content of about $7 \%$ of the whole body dry weight (Cartes and Maynou 1998).

To assess the substrate conversion by microbial organisms, we divided the biomass yield after 1 year by the organic $\mathrm{C}$ amount introduced by the chitin concentrations (Boetius and Lochte 1996). Results indicated that of the low, medium and high chitin- $\mathrm{C}$ amounts added to the enrichments, 6, 26 and $31 \%$ were converted into microbial biomass after 1 year, respectively. Despite the high chitin concentration, its degradation rate has been rarely estimated in marine environment directly (Herwig et al. 1988; Poulicek and Jeuniaux 1991; Kirchner 1995). It is commonly assumed that chitin must be degraded at the same rate as it is produced because chitin does not accumulate to a large extent in most marine sediments (Poulicek and Jeuniaux
1991). Indeed, Poulicek and Jeuniaux (1991) demonstrated that about $90 \%$ of chitin produced in the water column in marine environments was digested within $150 \mathrm{~h}$. In sediments, chitin digestion took longer than in the open water, taking at least 1 year. We assume that in contrast to the medium and high chitin treatments the lowest chitin amount of $1.3 \mathrm{gm}^{-2}$ was already consumed after 1 year. Furthermore, in sediments with medium and high chitin amounts the selection of chitinoclastic communities might have increased over time as a result of higher carbon amounts entering into the system, possibly explaining variations in substrate conversion. In addition, potential losses due to meiofaunal and microeukaryotic grazers could not be completely avoided since the trays were covered by $5 \mathrm{~mm}$ mesh size grids. It is also likely that additional organic materials may have been introduced from the water column to the sediment trays during 1 year. This effect, however, contributed only marginally to changes in microbial biomass, as suggested by the only small variations in microbial abundance detected in control sediments (Fig. 1a).

Shifts in bacterial community structure as a response to chitin inputs

Several studies have already shown that microbial communities are able to respond within short time to variations in the quality and quantity of organic matter supply by changes in their composition (Riemann et al. 2000; Eiler et al. 2003). These short-term shifts were generally accompanied by a functional response of bacterial communities. Our results from T-RFLP analysis (see Electronic Supplementary Material) also showed changes in community structure during incubation for 7 days. Interestingly here, rapid community changes apparently occurred without concomitant changes in microbial growth and activity (Fig. 1). Cluster analysis of T-RFLP data generally indicated the existence of three well-defined clusters (Fig. 2), which were consistent with differences in incubation times and sediment treatment. Cluster composed of control samples at different incubation times indicated that communities in sediments without additional chitin remained similar in their composition during the duration of the whole experiment. Unfortunately, we do not have any information about bacterial communities in natural deep-sea sediments that were not treated by freezing which may lead to community alteration (Stocum and Plante 2006). Our results indicated, however, that there were only minor structural variations between communities in initial control samples and those incubated for 1 year in which the community structure was presumably representative for those naturally present in deep-sea sediments at the experimental site due to gradual colonisation by indigenous populations. Additionally, 


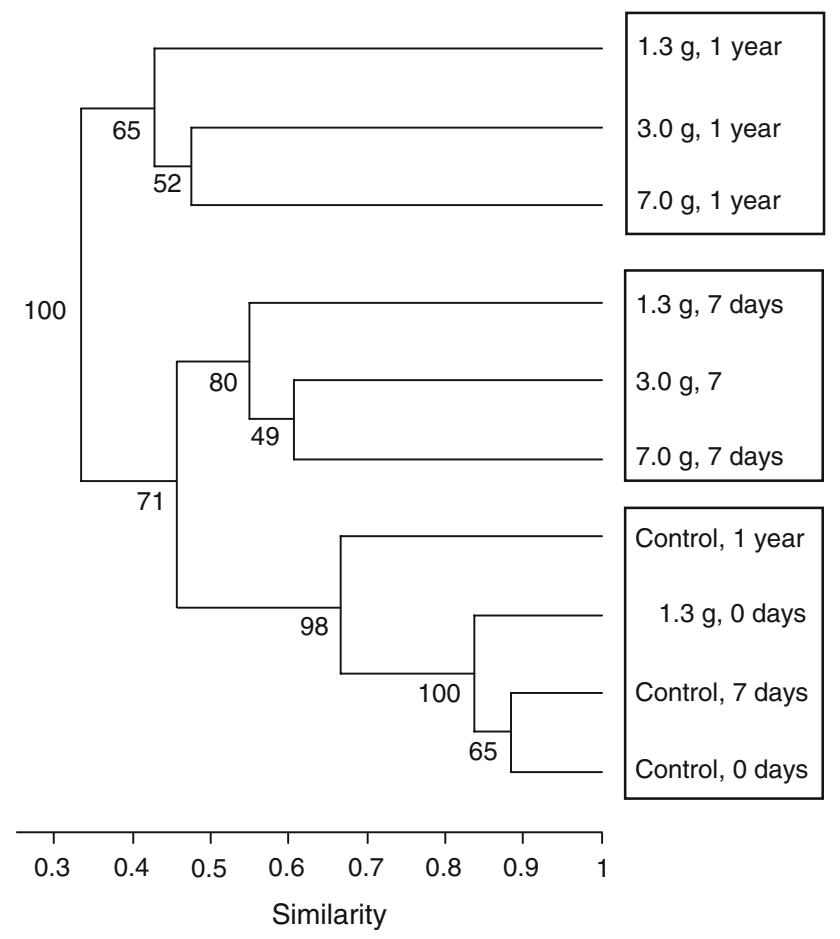

Fig. 2 Cluster analysis of T-RFLP data. The UPGMA dendrogram was constructed based on OTU presence/absence data obtained by T-RFLP analysis of the different sediment samples. Nodal support was assessed by 100 bootstrap replicates

initial community data from sediments amended with the lowest chitin concentration revealed only a marginal effect of microbes possibly introduced by the non-sterilised chitin on community structure identified in deep-sea sediments. T-RFLP profiles from these initial chitin-amended sediments were remarkably similar to those from control sediments without chitin (Fig. 2). In general, bacterial community structure in chitin-amended sediments was found to be gradually more dissimilar over the course of the experiment, suggesting that chitin had a time-dependent effect on the resident bacterial communities. Indeed, sample points were found to be more spread in the two- dimensional nMDS plot with increasing incubation time, indicating more variability in community structure (Fig. 3). Despite the difficulty of obtaining enough materials to perform T-RFLP analyses when setting up the experiment at 2,500 $\mathrm{m}$ water depth, the effects of both incubation time and chitin input on community structure were confirmed by redundancy analysis $(P=0.031$ based on 1,000 Monte Carlo permutations). Further variation partitioning of the biological variation into the respective effects of the two factors indicated that chitin input was the most important factor (12\% of biological variation was explained by the factor alone when taking duration of the experiment as a covariable), closely followed by the duration of incubation (9\%; data not shown). The total amount of unexplained biological variation was $79 \%$, which yet suggests that unmeasured factors would also need to be added in the future to better understand community dynamics in deep-sea sediments.

Few studies have demonstrated that metabolic change following alterations of environmental conditions (e.g. substrate amendments) may occur without simultaneous changes in bacterial community structure (Riemann and Middelboe 2002; Findlay and Sinsabaugh 2003). In contrast, mesocosm experiments conducted with manipulated dissolved organic matter (DOM) concentrations in freshwater environments (Judd et al. 2006) demonstrated that effects of changing DOM supply on bacterial productivity were mediated by initial shifts in community structure. Similarly, our results suggest that for deep-sea sediments, a functional response of microbial communities following a large chitin input may be triggered by an initial change in community structure before efficient utilisation of chitin compounds can be made. It may be also envisaged that the selection of specific populations (e.g. efficient chitin degraders) may accelerate over time as a function of the amount of carbon entering into the system.

Our results revealed chitin-dependent microbial responses and that POM supply can shape benthic microbial
Fig. 3 Non-metric multidimensional scaling $(n M D S)$ ordination of T-RFLP data based on Dice dissimilarities amongst samples. Full and empty symbols correspond to chitin-amended and not-amended controls. The size of full symbols increases with increasing chitin concentration

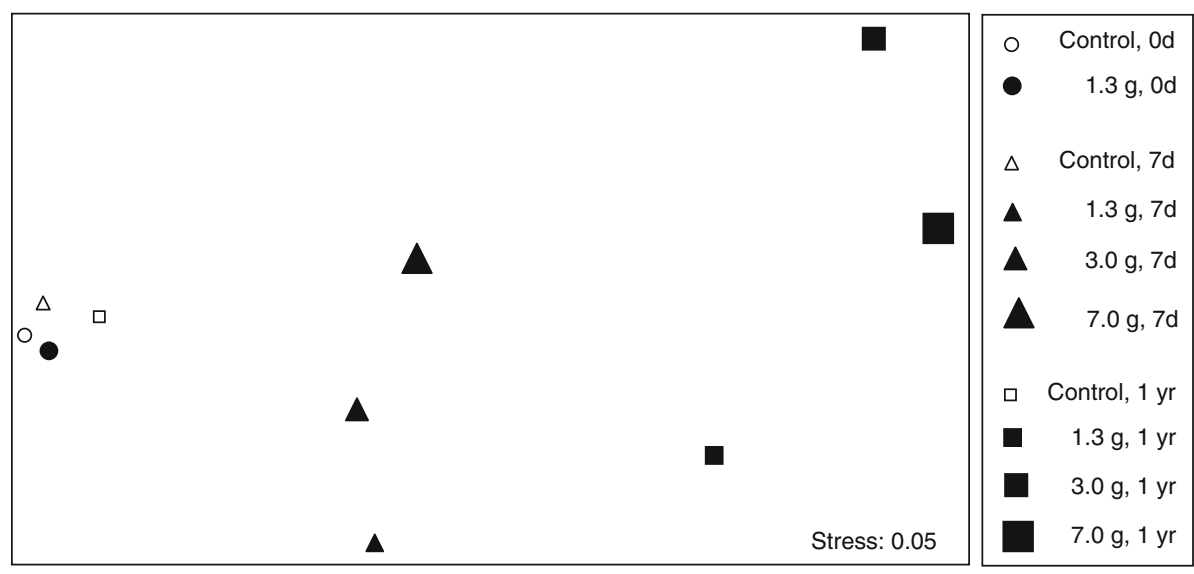


communities in the deep Arctic Ocean. Unfortunately, the lack of replication limited the analysis of significance of our results since the variation within each treatment was unknown. Therefore, further experiments in other deep-sea regions and greater replication are needed to establish the generality of these findings. To our knowledge, this is the first in situ study that describes responses of microbial abundance, activity potential and community structure over a long-term period. Future investigations will be dedicated to the assessment of the fate and rate of chitin degradation by using radiolabeled substrates. Furthermore, by using phylogenetic analysis of the microbial communities conjointly enriched under high chitin inputs and novel approaches, like MARFISH and stable isotope probing, we will be able to identify the microbes involved in recycling this highly insoluble organic substrate.

Acknowledgments We gratefully like to thank the ship officers and crew of the German research-icebreaker 'Polarstern' for their help during the expeditions to HAUSGARTEN in summers 2004 and 2005. Experiments with our free-falling benthic lander would not have been possible without the support of J. Wegner and I. Schewe. We are also indebted to I. Kolar for assistance with the sample preparation, biochemical analyses. We wish to thank A. Boetius, Gustavo Fonseca and Fabiane Gallucci for useful comments and discussions.

Open Access This article is distributed under the terms of the Creative Commons Attribution Noncommercial License which permits any noncommercial use, distribution, and reproduction in any medium, provided the original author(s) and source are credited.

\section{References}

Barnett PRO, Watson J, Conelly D (1984) A multiple corer for taking virtually undisturbed samples from shelf, bathyal and abyssal sediments. Oceanol Acta 7:399-408

Boetius A, Lochte K (1994) Regulation of microbial enzymatic degradation of organic matter in deep-sea sediments. Mar Ecol Prog Ser 104:299-307

Boetius A, Lochte K (1996) Effect of organic enrichments on hydrolytic potentials and growth of bacteria in deep-sea sediments. Mar Ecol Prog Ser 140:239-250

Børsheim KY, Bratbak G, Heldal M (1990) Enumeration and biomass estimation of planktonic bacteria and viruses by transmission electron microscopy. Appl Environ Microbiol 56:352-356

Bühring SI, Lampadariou N, Moodley L, Tselepides A, Witte U (2006) Benthic microbial and whole-community response to different amounts of ${ }^{13} \mathrm{C}$-enriched algae: In situ experiments in the deep Cretan Sea (Eastern Mediterranean). Limnol Oceanogr 51:157-165

Cartes JE, Maynou F (1998) Food consumption by bathyal decapod crustacean assemblages in the western Mediterranean: predatory impact of megafauna and food the consumption food supply balance in a deep-water food web. Mar Ecol Prog Ser 171:233-246

Cauchie H-M (2002) Chitin production by arthropods in the hydrosphere. Hydrobiology 470:63-96

Christiansen B, Boetius A (2000) Mass sedimentation of the swimming crab Charybdis smithii (Crustacea: Decapoda) in the deep Arabian Sea. Deep Sea Res II 47:2673-2685

Cottrell MT, Kirchman DL (2000) Natural assemblages of marine proteobacteria and members of Cytophaga-Flavobacter cluster consuming low- and high-molecular-weight dissolved organic matter. Appl Environ Microbiol 66:1692-1697

Deming JW (1985) Bacterial growth in deep-sea sediment trap and boxcore samples. Mar Ecol Prog Ser 25:305-312

Deming JW, Baross JA (1993) The early diagenesis of organic matter: bacterial activity. In: Engel MH, Macko SA (eds) Organic geochemistry: principles and application. Plenum Press, New York, pp 119-144

Dice LR (1945) Measures of the amount of ecological association between species. Ecology 26:297-302

Eiler A, Langenheder S, Bertilsson S, Tranvik LJ (2003) Heterotrophic bacterial growth efficiency and community structure at different natural organic carbon concentrations. Appl Environ Microbiol 69:3701-3709

Findlay SEG, Sinsabaugh RL (2003) Response of hyporheic biofilm metabolism and community structure to nitrogen amendments. Aquat Microb Ecol 33:127-136

Gooday GW (1990) The ecology of chitin degradation. Adv Microb Ecol 11:387-430

Grossmann S, Reichardt W (1991) Impact of Arenicola marina on bacteria in intertidal sediments. Mar Ecol Prog Ser 77:85-93

Hammer O, Harper DAT, Ryan PD (2001) PAST: Paleontological statistics software package for education and data analysis. Palaeontol Electr 4:1-9

Herwig R, Pellerin N, Irgens R, Maki J, Staley J (1988) Chitinolytic bacteria and chitin mineralisation in the marine waters and sediments along the Antarctic Peninsula. FEMS Microbiol Ecol 53:101-112

Hirche H-J, Kosobokova K (2007) Distribution of Calanus finmarchicus in the northern North-Atlantic and Arctic Ocean: expatriation and potential colonisation. Deep Sea Res II 54:2729-2747

Hirche H-J, Muyakshin S, Klages M, Auel H (2006) Aggregation of the Arctic copepod Calanus hyperboreus over the ocean floor of the Greenland Sea. Deep Sea Res I 53:310-320

Hoppe H-G (1983) Significance of exoenzymatic activities in the ecology of brackish water: measurements by means of methylumbelliferyl-substrates. Mar Ecol Prog Ser 11:299-308

Judd KE, Crump BC, Kling GW (2006) Variation in dissolved organic matter controls bacterial production and community composition. Ecology 87:2068-2079

Kirchner M (1995) Microbial colonisation of copepod body surfaces and chitin degradation in the sea. Helgoländer Meeresunters 49:201-212

Meyer-Reil LA (1983) Benthic response to sedimentation events during autumn to spring at a shallow water station in the Western Kiel Bight. Mar Biol 77:247-256

Moodley L, Middelburg JJ, Boschker HTS, Duineveld GCA, Pel R et al (2002) Bacteria and Foraminifera: key players in a shortterm deep-sea benthic response to phytodetritus. Mar Ecol Prog Ser 236:23-29

Poremba K (1995) Hydrolytic enzymatic activity in deep-sea sediments. FEMS Microbiol Ecol 16:213-222

Poulicek M, Jeuniaux C (1989) Chitin biomass in marine sediments. In: Skjak-Brek G, Anthonsen T, Sandford P (eds) Chitin and Chitosan. Elsevier, London, pp 151-160

Poulicek M, Jeuniaux C (1991) Chitin biodegradation in marine environments: an experimental approach. Biochem Syst Ecol 19:385-394

Ramette A (2007) Multivariate analyses in microbial ecology. FEMS Microbiol Ecol 62:142-160

Ramette A, Tiedje JM (2007) Multiscale responses of microbial life to spatial distance and environmental heterogeneity in a patchy ecosystem. Proc Nat Acad Sci USA 104:2761-2766

Rappé MS, Giovannoni SJ (2003) The uncultured microbial majority. Ann Rev Microbiol 54:369-394

Riemann L, Middelboe M (2002) Stability of bacterial and viral community compositions in Danish coastal waters as depicted 
by DNA fingerprinting techniques. Aquat Microb Ecol 27:219-232

Riemann L, Steward GF, Azam F (2000) Dynamics of bacterial community composition and activity during a mesocosm diatom bloom. Appl Environ Microbiol 66:578-587

Sokal RR, Rohlf FJ (1995) Biometry, 3rd edn. Freeman WH and Company, San Francisco

Sokolova MN (1994) Euphausiid 'dead body rain' as a source of food for abyssal benthos. Deep Sea Res I 41:741-746

Soltwedel T, Bauerfeind E, Bergmann M et al (2005) HAUSGARTEN-multidisciplinary investigations at a deep-sea long-term observatory in the Arctic Ocean. Oceanography 18:46-61

Stocum ET, Plante CJ (2006) The effect of artificial defaunation on bacterial assemblages of intertidal sediments. J Exp Mar Biol Ecol 337:147-158
Vetter Y-A, Deming JW (1994) Extracellular enzyme activity in the Arctic Northeast Water polynya. Mar Ecol Prog Ser 114:23-34

Wakeham S, Lee C (1993) Production, transport, and alteration of particulate organic matter in the marine water column. In: Engel MH, Macko SA (eds) Organic geochemistry. Plenum Press, New York, pp 145-169

Węsławski JM, Legeżyńska J (1998) Glaciers caused zooplankton mortality? J Plankton Res 20:1233-1240

Witte U, Wenzhöfer F, Sommer S, Boetius A, Heinz P, Aberle N, Sand M, Abraham W-R, Jörgensen BB, Pfannkuche O (2003) In situ experimental evidence of the fate of a phytodetritus pulse at the abyssal sea floor. Nature 424:763-766 